University of Windsor

Scholarship at UWindsor

2008

\title{
Vocal behavior of the critically endangered Niceforo's Wren (Thryothorus nicefori)
}

\author{
Sandra Valderrama \\ Jorge E. Parra \\ Nicolás Dávila \\ Daniel J. Mennill \\ University of Windsor
}

Follow this and additional works at: https://scholar.uwindsor.ca/biologypub

Part of the Biology Commons

\section{Recommended Citation}

Valderrama, Sandra; Parra, Jorge E.; Dávila, Nicolás; and Mennill, Daniel J., "Vocal behavior of the critically endangered Niceforo's Wren (Thryothorus nicefori)" (2008). Auk, 125, 2, 395-401.

https://scholar.uwindsor.ca/biologypub/1165

This Article is brought to you for free and open access by the Department of Biological Sciences at Scholarship at UWindsor. It has been accepted for inclusion in Biological Sciences Publications by an authorized administrator of Scholarship at UWindsor. For more information, please contact scholarship@uwindsor.ca. 


\section{Vocal Behavior of the Critically Endangered Niceforo's Wren (Thryothorus Nicefori)}

Author(s): Sandra Valderrama, Jorge Parra, Nicolás Dávila, and Daniel J. Mennill

Source: The Auk, 125(2):395-401.

Published By: The American Ornithologists' Union

https://doi.org/10.1525/auk.2008.06249

URL: http://www.bioone.org/doi/full/10.1525/auk.2008.06249

BioOne (www.bioone.org) is a nonprofit, online aggregation of core research in the biological, ecological, and environmental sciences. BioOne provides a sustainable online platform for over 170 journals and books published by nonprofit societies, associations, museums, institutions, and presses.

Your use of this PDF, the BioOne Web site, and all posted and associated content indicates your acceptance of BioOne's Terms of Use, available at www.bioone.org/page/terms_of_use.

Usage of BioOne content is strictly limited to personal, educational, and non-commercial use. Commercial inquiries or rights and permissions requests should be directed to the individual publisher as copyright holder. 


\title{
VOCAL BEHAVIOR OF THE CRITICALLY ENDANGERED NICEFORO'S WREN (THRYOTHORUS NICEFORI)
}

\author{
Sandra Valderrama, ${ }^{1,2,3,4}$ Jorge Parra, ${ }^{1,2}$ Nicolás Dávila, ${ }^{1,2}$ and Daniel J. Mennill ${ }^{3}$ \\ ${ }^{1}$ Universidad de Los Andes, Carrera 1 no. 18A-10, Bogotá, Colombia; ${ }^{2}$ Fundación ProAves Colombia, Carrera 20 no. 36-61, Bogotá, Colombia; and \\ ${ }^{3}$ Biology Department, University of Windsor, Windsor, Ontario N9B 3P4, Canada
}

\begin{abstract}
AвSTRACT.-Niceforo's Wren (Thryothorus nicefori) is a critically endangered songbird endemic to dry forests of the Chicamocha Valley in central Colombia. Discovered in 1946 and "red-listed" by the IUCN since 1988, Niceforo's Wren faces a threat of extinction because of its limited habitat range and increasing deforestation for agriculture and livestock. This species has been poorly studied, and its vocal behavior is yet undescribed. We provide the first description of the vocalizations of Niceforo's Wren, based on analyses of recordings from 29 individuals (more than half of all estimated living individuals of this species). We examined the fine structure of their songs, the pattern of solo and duet singing behavior, and the song repertoire size of males and females. Both sexes produce solo songs, coordinated vocal duets, and a variety of calls. Songs have a stereotyped syntax including one or more introductory syllables, a trill of rapidly repeated syllables, and a frequency-modulated terminal syllable. Males have a repertoire of at least 12-21 different song types, whereas females have a repertoire of at least 7-9. Both sexes sing solo songs with eventual variety. Male songs are more complex and have lower frequency characteristics, whereas female songs are shorter, with fewer syllable types and fewer syllable repeats. Duets involve mated pairs singing in a coordinated fashion using the same song types from their solo repertoires. Duets typically begin with a male song followed by a female song and show variable levels of complexity involving one to two songs given by each individual. Our results provide a foundation for monitoring Niceforo's Wrens and facilitating conservation of this critically endangered species. Received 27 November 2006, accepted 17 July 2007.
\end{abstract}

Key words: Colombia, conservation, duet, Neotropical dry forest, Niceforo's Wren, song, Thryothorus nicefori.

\section{Comportamiento Vocal de la Especie en Peligro Crítico Thryothorus nicefori}

RESUMEN.-Thryothorus nicefori es un ave canora endémica de los bosques secos del valle del río Chicamocha, localizado en el centro de la Cordillera Oriental de los Andes colombianos. Esta especie fue descrita en 1946 e incluida en la lista roja por la IUCN desde 1988. T. nicefori enfrenta una tremenda amenaza de extinción debido a su limitado rango de hábitat y a la continua deforestación para la agricultura. Esta especie ha sido poco estudiada y su comportamiento vocal no se ha descrito todavía. Aquí presentamos la primera descripción de las vocalizaciones de T. nicefori, basada en el análisis de grabaciones de 29 individuos (más de la mitad de todos los individuos vivientes de esta especie). Examinamos las características estructurales de sus cantos, el patrón del comportamiento vocal con respecto a solos y duetos, y el tamaño del repertorio de cantos para machos y hembras. Ambos sexos producen cantos en solo, duetos vocales coordinados y una variedad de llamados. Los cantos tienen una sintaxis estereotípica que incluye una o más sílabas introductorias, un trino con sílabas que se repiten rápidamente y una sílaba terminal con frecuencia modulada. Los machos tienen un repertorio de por lo menos 12 a 21 tipos de canto diferentes, mientras que las hembras tienen un repertorio de por lo menos 7 a 9 tipos de canto diferentes. Ambos sexos emiten cantos en solo y con una variación eventual. Los cantos del macho son más complejos y tienen valores más bajos de frecuencia, mientras que los cantos de la hembra son más cortos y tienen menos tipos de sílabas, así como menos repeticiones de estas sílabas. Los duetos involucran parejas establecidas que cantan en forma coordinada, para lo cual usan los mismos tipos de canto contenidos en sus repertorios de cantos solo. Los duetos típicamente comienzan con un canto del macho seguido por un canto de la hembra, y muestran niveles variables de complejidad que involucran de uno a dos cantos aportados por cada individuo. Nuestros resultados proporcionan un fundamento para el monitoreo de T. nicefori y facilitan la conservación de esta especie en peligro crítico.

${ }^{4}$ E-mail: svalderrama@proaves.org

The Auk, Vol. 125, Number 2, pages 395-401. ISSN 0004-8038, electronic ISSN 1938-4254. (C) 2008 by The American Ornithologists' Union. All rights reserved. Please direct all requests for permission to photocopy or reproduce article content through the University of California Press's Rights and Permissions website, http://www. ucpressjournals.com/reprintInfo.asp DOI: 10.1525/auk.2008.06249 
NEOTROPICAL DRY FORESTS face an ongoing conservation threat from agriculture and livestock. Dry forests are easily cleared for pasture and, consequently, Neotropical dry forests rank among the most threatened ecosystems on Earth (Janzen 1988). Dry forests have great importance because of high levels of avian endemism that arose through allopatric speciation during the Pleistocene epoch (Pennington et al. 2000), yet the biology of many birds within these forests is poorly studied (Murphy and Lugo 1986). Documentation and preservation of the endemic species in dry-forest ecosystems is of paramount importance in the Neotropics. Moreover, documentation and preservation of endemic species is important for understanding patterns of biological diversity and for deepening our knowledge of patterns and processes in evolution.

In Colombia, dry forests are patchily distributed along the Caribbean coast, in the inter-Andean valleys, and in the eastern Andes. However, it is estimated that only $1.5 \%$ of the original dry forest survives (Etter 1993). One little-studied Neotropical dry-forest remnant is found in the Chicamocha Valley in the eastern Andes of Colombia. The Chicamocha Valley is home to two endemic avian subspecies, the Blue-crowned Motmot (Momotus momota olivaresi) and Golden-winged Sparrow (Arremon schlegeli canidorsum), as well as the endemic Niceforo's Wren (Thryothorus nicefori).

Niceforo's Wren is a critically endangered songbird that persists only in the remaining patches of tropical dry forest in the Chicamocha Valley (Hilty and Brown 1986), with an estimated total population of $<50$ adult individuals (BirdLife International 2000), and it faces an ongoing threat because of habitat loss to farming (S. Valderrama et al. pers. obs.). Niceforo's Wren was "red-listed" by the International Union for the Conservation of Nature and Natural Resources (IUCN) in 1988 as a threatened species (Collar and Andrew 1988) and has been listed as a critically endangered species from 1994 (Collar et al. 1994) to present (BirdLife International 2004). Like many other wrens in the genus Thryothorus, Niceforo's Wren is nonmigratory, with long-term territoriality and stable, socially monogamous pair bonds (Valderrama et al. 2007). Niceforo's Wrens were only recently described (Meyer de Schauensee 1946), and most aspects of their ecology and behavior are unknown or poorly understood (Brewer 2001). Their voice is undescribed (Hilty and Brown 1986, Ridgely and Tudor 1989, Brewer 2001) except for passing comments that they sound like Rufous-and-white Wrens (T. rufalbus; Collar et al. 1992, LopézLanús and Cadena 2002).

We collected recordings during an intensive search for Niceforo's Wrens in the Chicamocha Valley. Here, we describe, for the first time, the vocalizations and singing behavior of Niceforo's Wren. The present study is fundamental to understanding the communication system of this species. Vocal descriptions provide a valuable instrument for population census surveys and monitoring, particularly for birds of conservation concern. It is important to promote both documentation and conservation actions to preserve Niceforo's Wren, and a formal description of the vocalizations of this critically endangered species is an important first step.

\section{Methods}

Study area.-Recordings were made in the remnant forests within the Chicamocha, Fonce, and Suárez river basins $\left(6^{\circ} 32^{\prime} \mathrm{N}, 73^{\circ} 07^{\prime} \mathrm{W}\right)$, an isolated area of Neotropical dry forest in the eastern Andes of
Colombia. The landscape in this area has been heavily modified by intense anthropogenic pressure. Natural habitat has been replaced with farms producing mostly coffee (Coffea arabica), beans (Phaseolus vulgaris), maize (Zea mays), and tobacco (Nicotiana tabacum), as well as livestock-mainly cows (Bos taurus) and goats (Capra aegagrus). The habitat is scattered in patches consisting of tangled riparian vegetation, generally secondary semideciduous forest dominated by species such as Guácimo (or Bastard cedar; Guazuma ulmifolia). In some areas, primary forest remains, with characteristic dominant, broad-leaved, evergreen trees including Kapok tree (Ceiba pentandra) and Caracolí (or Wild Cashew; Anacardium excelsum).

Recordings and song analysis.-We recorded songs during two periods in two years. Five breeding pairs and three unpaired males were recorded between 29 July and 28 December 2004, and six breeding pairs and five unpaired males were recorded between 19 July and 9 August 2006. Recordings in 2006 were made in different locations than those in 2004 (recording locations were separated by $9.5-20.25 \mathrm{~km}$ ), and comparison of sound spectrograms confirmed that no individuals were sampled in both 2004 and 2006. Nine birds were individually marked with distinctive colorband combinations. The remaining individuals were identifiable by location; all banded birds were territorial and seldom moved beyond territory boundaries (S. Valderrama pers. obs.). In both years, most birds were building nests at the time of recording.

Focal recordings were collected between 0530 and 1000 hours using a Sony WMD6C tape recorder with a Sennheiser ME66 directional microphone. Tapes were digitized with AUDITION software (Adobe, San Jose, California) with a $44.1-\mathrm{kHz}$, 16-bit sampling frequency. We used SYRINX-PC sound-analysis software (J. Burt, Seattle, Washington) to generate and analyze sound spectrograms of all songs from all recordings. Song types were easily distinguished, because Niceforo's Wrens' repertoires are composed of songs of discrete types with highly stereotyped time and frequency characteristics. Rarely, birds omitted one or two introductory syllables or trill syllables during a bout of songs with otherwise identical time and frequency characteristics; we considered such variants to be the same song type. We estimated repertoire size for all individuals for which we had $>100$ recorded songs. Because of observed similarities between the songs of Niceforo's Wrens and Rufous-and-white Wrens (Ridgely and Tudor 1989), we analyzed duets and song structure according to the criteria used by Mennill and Vehrencamp (2005). Typically, three components can be distinguished in Rufous-and-white Wrens' songs: an introduction composed of varied syllables, a trill of rapidly repeated syllables, and a frequency-modulated terminal syllable (Mennill and Vehrencamp 2005). For each individual song type, we isolated the song with the highest signal-to-noise ratio and counted the number of syllables, the number of types of syllables, the number of trill syllables, the number of changes in the slope of the terminal syllable, the length of the entire song, the length of the terminal syllable, and the bandwidth (maximum minus minimum frequency) of the terminal syllable. We also used AUDITION to find the frequency of maximum amplitude (FMA) for the trill section and the terminal syllable of each song type. Our measurement resolution was $5 \mathrm{~ms}$ for all time measurements and $10 \mathrm{~Hz}$ for all frequency measurements. 
We calculated song rate for both males and females as the number of songs per minute over the total period of each recording (between 10 and $219 \mathrm{~min}$ ). To measure song rate independently of long pauses in singing, we also calculated song rate within bouts of song by discarding intersong latencies $>60 \mathrm{~s}$.

We defined "duets" as bouts of songs emitted by a paired male and female either in an overlapping fashion or separated by $<1 \mathrm{~s}$ of silence (Mennill and Vehrencamp 2005). Each duet was categorized as a simple, sandwich, or complex duet (after Mennill and Vehrencamp 2005) to examine the frequency and complexity of Niceforo's Wrens' duets.

Sample size and statistical analyses.-We recorded 5,253 songs from 11 pairs (average $\pm \mathrm{SE}=351.7 \pm 86.6$ songs) and 8 unpaired males (173.0 \pm 73.9 songs). Analyses of repertoires are based on recordings of 220 song types from 18 males and 11 females. For 12 males, we logged $>100$ songs and analyzed the repertoire size as cumulative number of song types versus the number of changes in song type recorded. Variation between males and females was examined using $t$-tests when data were normally distributed and Mann-Whitney $U$-tests when data were non-normally distributed. Song rate was calculated for 11 males and 6 females for which we had recordings $>30 \mathrm{~min}$. To evaluate whether one sex initiated duets more often than the other, we used a chi-square test to compare the proportion of male- and female-initiated duets with a null hypothesis of $50 \%$ of duets initiated by each sex. All measurements are reported as mean $\pm \mathrm{SE}$.

\section{Results}

Song structure.-Male and female Niceforo's Wrens sing both solo and duet songs and produce a variety of calls. The solo songs of both sexes consist of a variety of low-pitched, flute-like syllables (Fig. 1). The syllabic characteristics of songs vary significantly between the sexes. Male songs are composed of 3-33 syllables (average: $9.2 \pm 0.6$ syllables), whereas female songs are composed of $2-17$ syllables (average: $6.6 \pm 0.7$ syllables; $t=3.0$, $P=0.007, n=29$ ). Male songs feature two to six types of syllables (average: $3.6 \pm 0.1$ syllable types), whereas female songs feature two to four types of syllables (average: $3.1 \pm 0.2$ syllable types; $t=3.0, P=0.007, n=29$ ). Males usually sing one to five introductory syllables (average: $1.8 \pm 0.1$ syllables), whereas females usually sing one to two introductory syllables (average: $1.2 \pm 0.2$ syllables; Mann-Whitney $U=50.0, P=0.03, n=29)$. Occasionally, song types lack introductory syllables ( 9 of 180 male song types and 4 of 40 female song types lacked introductory syllables but contained both trill and terminal syllables). Songs generally include a sequence of rapidly repeated syllables that constitute a trill. Trills vary in length from 2 to 28 repeated syllables in males

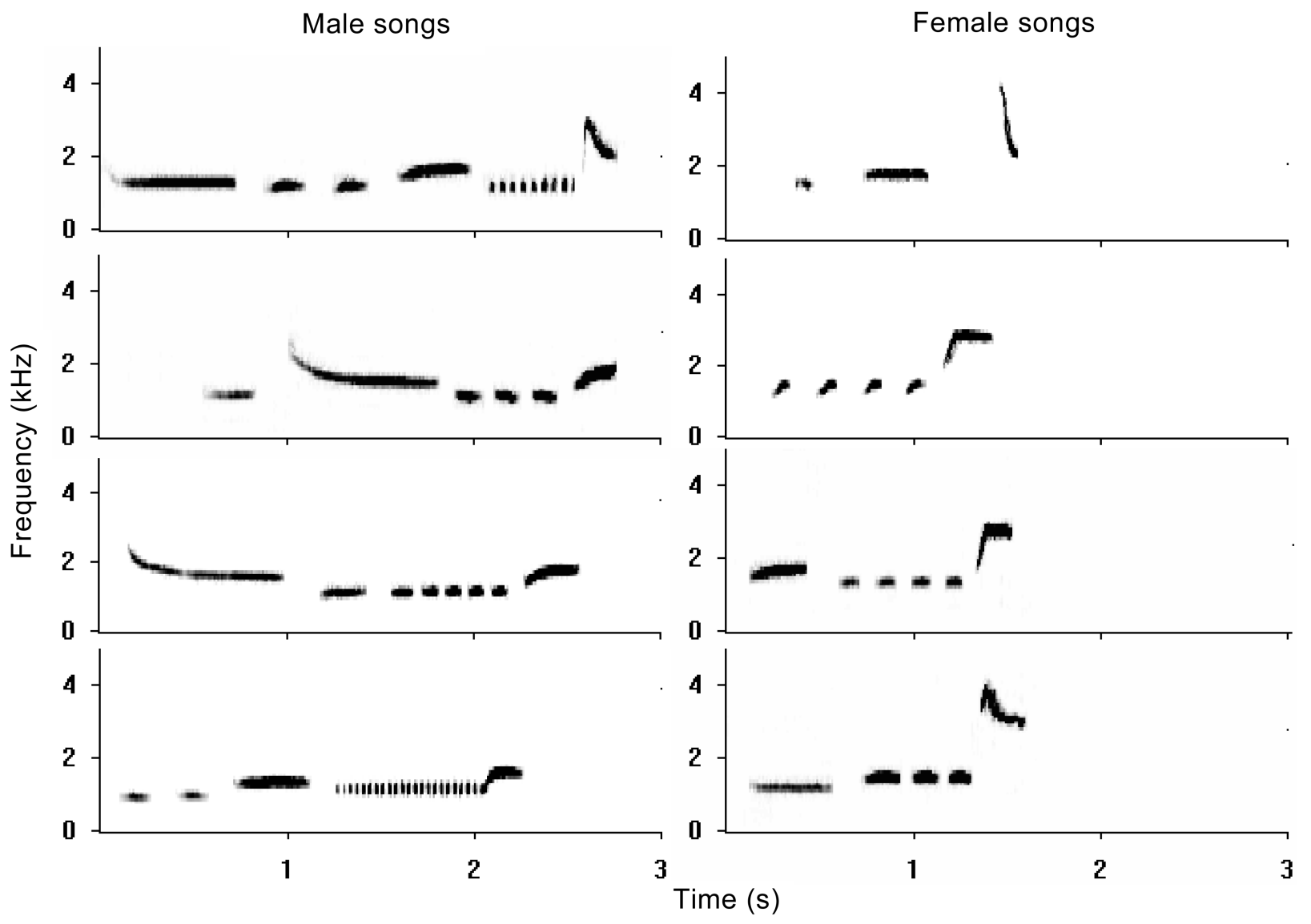

FIG. 1. Sound spectrogams of solo songs of male and female Niceforo's Wren. Four song types are shown for each sex. 


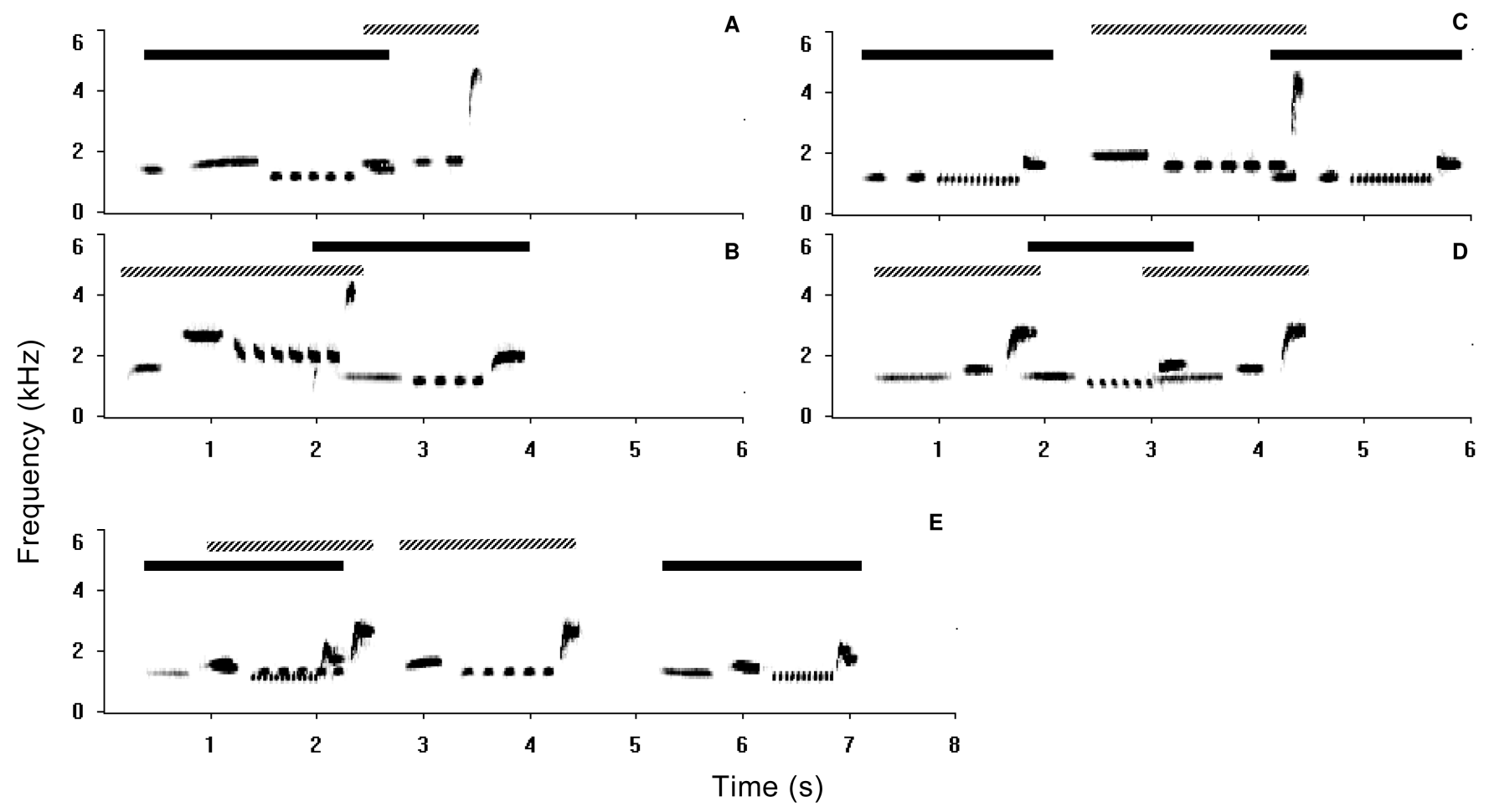

FIG. 2. Sound spectrograms of duets of Niceforo's Wren: simple duets initiated by (A) a male and (B) a female; "sandwich" duets with (C) two male songs and (D) two female songs; and (E) a complex duet initiated by a male, with two songs per individual. Male songs are highlighted with a solid bar, female songs with a hatched bar.

(average: $6.4 \pm 0.5$ syllables) and from 2 to 15 in females (average: $3.7 \pm 0.4$ syllables; $t=3.8, P=0.001, n=29$ ). Occasionally, the trill is omitted ( 3 of 180 male song types and 5 of 40 female song types lacked a trill but contained introductory and terminal syllables). At the end of all songs, a terminal syllable is uttered at a higher frequency than the rest of the song. Terminal syllables are usually frequency-modulated, with $0-3$ changes in the slope; number of frequency modulations did not differ significantly between males (1.6 \pm 0.1 changes in slope) and females $(1.8 \pm 0.2$ changes in slope; $t=0.6, P=0.55, n=28$ ).

Male and female Niceforo's Wrens exhibit significant differences in the time and frequency components of their songs. Male songs are $1.9 \pm 0.1 \mathrm{~s}$ long, whereas female songs are $1.6 \pm 0.1 \mathrm{~s}$ long $(t=3.3, P=0.003, n=28)$. The FMA is significantly higher in female trills $(1,379.4 \pm 51.6 \mathrm{~Hz})$ and female terminal syllables $(2,586 \pm$ $196.0 \mathrm{~Hz})$ than in male trills $(1,031.4 \pm 9.5 \mathrm{~Hz}$; Mann-Whitney $U=0.0, P<0.0001)$ and male terminal syllables $(1,938.1 \pm 69.6 \mathrm{~Hz}$; Mann-Whitney $U=24.0, P=0.001)$. Trill length is similar for males $(0.70 \pm 0.03 \mathrm{~s})$ and females $(0.71 \pm 0.10 \mathrm{~s} ; t=0.9, P=0.32$, $n=28)$. The bandwidth of the terminal syllable of male songs $(939.7 \pm 64.4 \mathrm{~Hz})$ is not significantly different from that of female songs (1,126.2 $\pm 140.9 .4 \mathrm{~Hz}$; Mann-Whitney $U=79.0, P=0.37)$.

Singing behavior.-Male song output is much higher than fe-

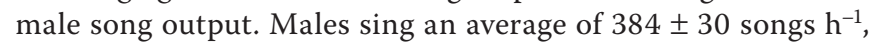
whereas females sing only $30 \pm 12$ songs $^{-1}(t=11.1, P<0.0001, n=$ 17). Both males and females sing in bouts that are punctuated by silent intervals. Within song bouts, the interval between consecutive songs is similar for males (one song every $12.1 \pm 1.0 \mathrm{~s}$ ) and females (one song every $9.7 \pm 1.4 \mathrm{~s} ; t=1.3, P=0.22, n=17$ ).

Duets.-Breeding partners create duets by combining the same songs that they produce as solos. The resulting duets vary in complexity and configuration (Fig. 2). Simple duets, in which the male and female each contribute one song to the duet, are the most common type, accounting for $90.8 \%(n=129)$ of all recorded duets $(n=142)$. Less often, birds produce more than one song per duet: 7.0\% $(n=10)$ are "sandwich" duets where one partner's song is preceded and followed by songs of its mate, and $2.1 \%(n=3)$ are complex duets involving two or more songs from each partner. In $74.6 \%(n=106)$ of all recorded duets, the male sang first and the female second; in $21.8 \%(n=31)$ of the remaining duets, the female sang first and the male second $\left(\chi^{2}=43.4, P<0.0001, n=137\right)$. Occasionally, individuals sang duets in which the start of partners' songs overlapped exactly (3.5\% of recorded duets).

Repertoire size.-Males have impressive song repertoires of $\geq 12$ song types. Song types are discrete and largely invariant, except for occasional omission of an introductory syllable or trill syllable. The species' song types are sufficiently distinctive that a human listener can discriminate song types without the use of sound spectrograms. For the 12 males from which we recorded $>100$ songs, we calculated a minimum repertoire size of 12-21 song types (Fig. 3A shows data for 3 of these 12 males). For the two females from which we recorded $>100$ songs, we calculated a minimum repertoire size of seven and nine song types, respectively (Fig. 3B). Repertoire sampling of both males and females was not 


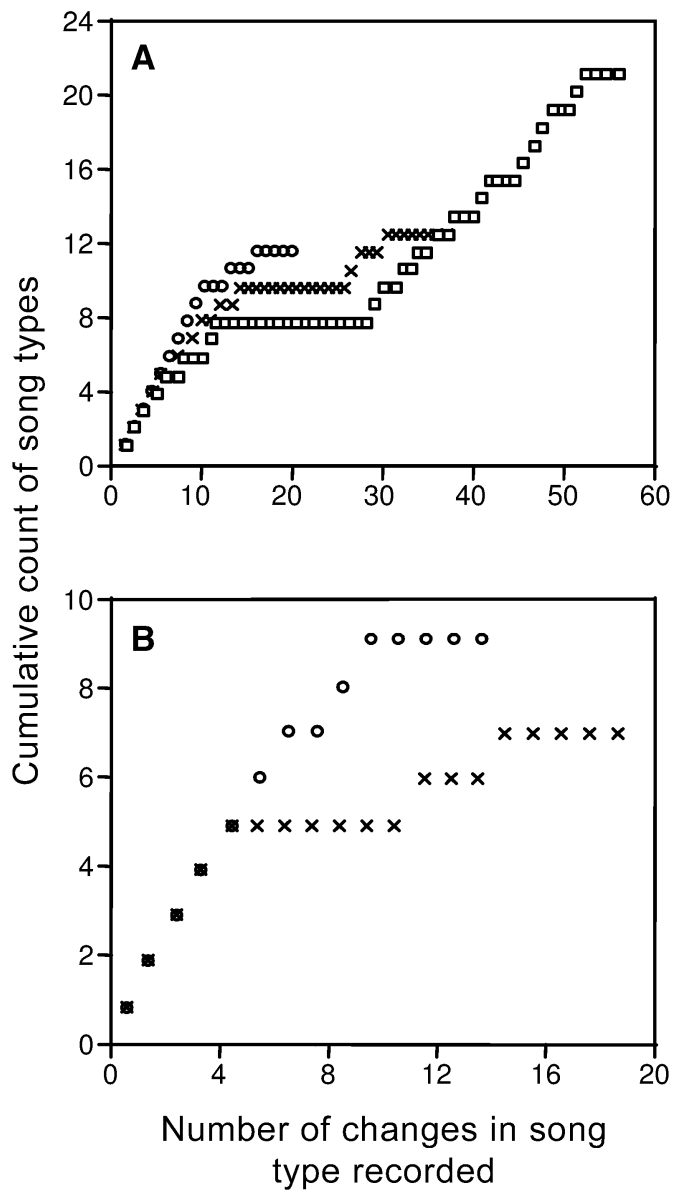

FIG. 3. Repertoire sizes of Niceforo's Wren shown as cumulative counts of novel song types detected versus the number of changes in song type recorded. (A) Cumulative count for repertoire sizes for three example males. (B) Cumulative count for repertoire sizes of two females.

exhaustive and, consequently, our repertoire estimates are conservative. Both males and females sing with eventual variety, repeating songs many times before switching to a new song type.

Calls.-Calls are emitted by both male and female Niceforo's Wrens. We detected five call types (Fig. 4). Three calls (onomatopoetically: "uaa," "crip," and "reow") were uttered as contact signals between males and females when they were separated from their mate by short distances but hidden from each other within thick vegetation, and also during nest construction when birds were close to their nest. "Clicks" were broadband calls often uttered as an alarm call, including occasions when they were heard in response to a potential predator, a Roadside Hawk (Buteo magnirostris). "Clicks" were also observed as an intense response to other species that were close to active nests and in response to playback of conspecific songs. We observed both males and females producing reow calls and "clicks," whereas we did not determine which sex produced uaa and crip calls because they were recorded only while birds were obscured in thick vegetation. Uiiu click calls were recorded from only two males, but we could not determine the contexts in which these calls were used.

\section{Discussion}

Niceforo's Wren produces a variety of distinctive songs and calls. Songs have a stereotyped syntax with a variable number of syllables arranged in three distinguishable parts (introduction, trill, terminal syllable). Both sexes sing, but males sing longer, more complex songs with lower-frequency trills and terminal syllables than females. Male songs consist of a larger number of syllables and more syllable types, whereas female songs are shorter, with a simpler structure and higher-frequency trills and terminal syllables. Females and males articulate trills of similar duration, but male trills usually contain more syllables, so that male songs have faster trill rates than female songs. Trill rate has been demonstrated to be a salient feature of the songs of the closely related Banded Wren (T. pleurostictus) for both male-male and femalemale assessments (Illes et al. 2006). Although trills in Niceforo's Wren typically consist of units with slightly or non-modulated frequencies, in contrast to the highly frequency-modulated trills of Banded Wrens, trill rate may nevertheless be important for assessment of partner quality.

The singing behavior of Niceforo's Wren is sexually distinctive. Males sing much more than females. During song bouts, males and females sing at similar rates, but males sing more bouts than females as well as more songs per bout. Both males and females have distinctive repertoires of song types, and males have larger repertoires than females. More extensive repertoire-sampling is necessary to reliably establish the upper limits of the repertoire size of Niceforo's Wrens, but male repertoires consist of a minimum of 12-21 song types, and female repertoires consist of a minimum of 7-9 song types. Duets most often begin with a male song followed by a female song, and duets typically contain one song from each of the duetting partners.

Niceforo's Wrens share similar song structure (introduction, trill, and terminal syllable) with Rufous-and-white Wrens. Mennill and Vehrencamp (2005) studied the singing and duetting behavior of a Costa Rican population of Rufous-and-white Wrens and uncovered substantial intersexual differences in the fine structure of songs. As in Rufous-and-white Wrens, we found that male Niceforo's Wrens sing more trill syllables per song than females, have larger repertoires, and sing lower-frequency trills and terminal syllables than females (Mennill and Vehrencamp 2005). In contrast to our findings in Niceforo's Wrens, male and female Rufous-and-white Wrens utter a similar number of syllable types per song and sing songs of similar duration, and Rufousand-white Wrens sing at higher rates than females during song bouts, whereas male and female Niceforo's Wrens sing at similar rates during song bouts (Mennill and Vehrencamp 2005). A detailed comparison between the songs of Niceforo's Wrens and recordings of Rufous-and-white Wrens throughout their geographic range is an important avenue for future research.

Mann et al. (2006) recently produced a new molecular phylogeny for Thryothorus and proposed dividing this paraphyletic group into four distinct genera. Given the observed similarity between Niceforo's and Rufous-and-white wrens (Meyer de Schauensee 1946), we believe that Niceforo's Wren belongs in the proposed 


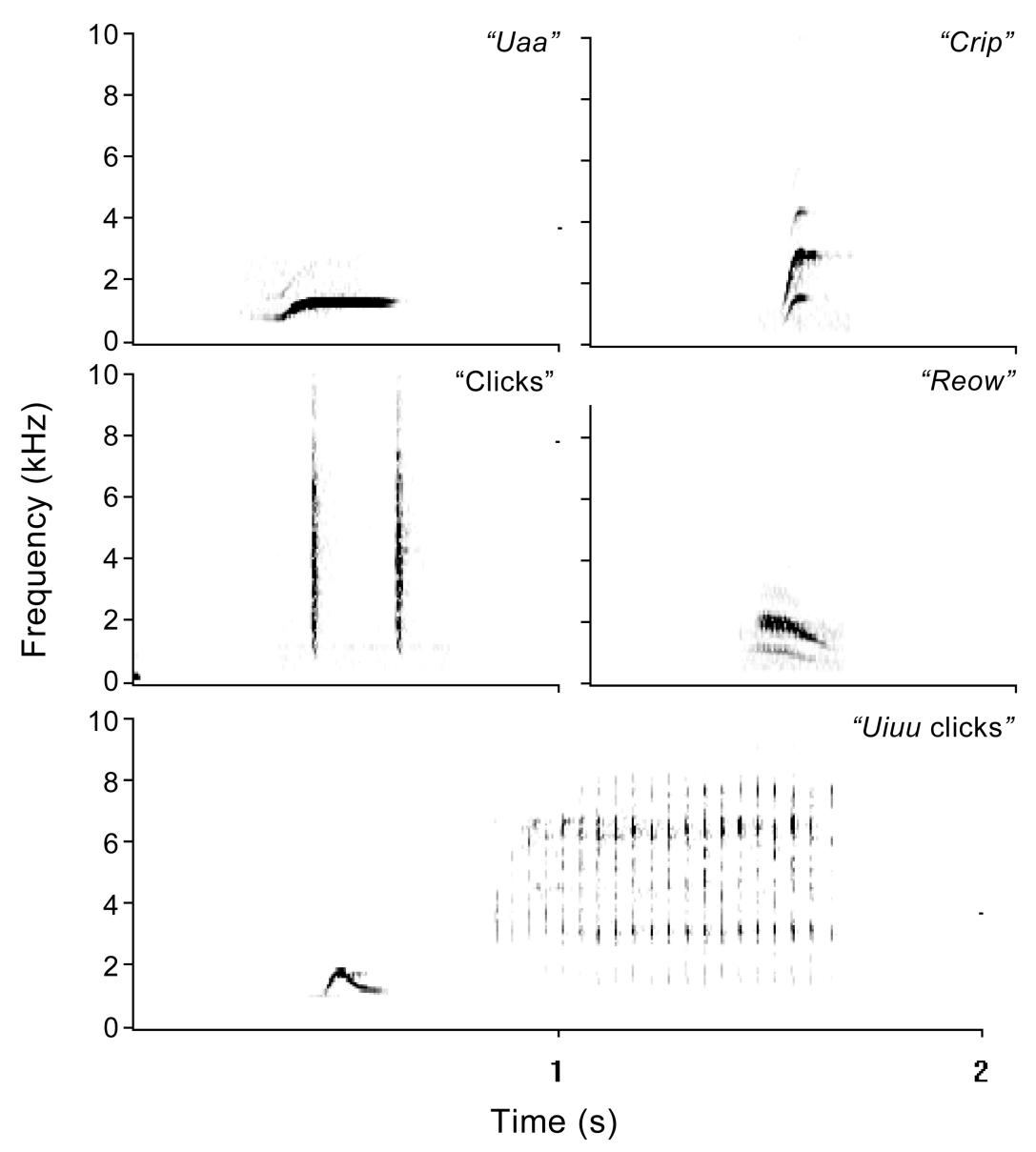

FIG. 4. Spectrograms of five call types of Niceforo's Wren.

genus Thryophilus along with Rufous-and-white Wren. Comparative studies of vocalizations and genetics of Niceforo's Wrens and other Neotropical wrens will be important to clarify and substantiate relationships between these taxa and within the genus Thryothorus (sensu lato).

Conservation actions are imperative to preserve the critically endangered Niceforo's Wren. Our analyses of vocal behavior provide a foundation for censusing and monitoring the reproductive activities of the remaining individuals. Their unique vocal features allow Niceforo's Wrens to be distinguished acoustically from other species and allow males and females to be distinguished without capturing them. Pairing status of Niceforo's Wrens is easily assessed by the presence of duets. The presence of many nonduetting, unpaired, territorial males in our study indicates that the number of breeding pairs in the extant population may be declining. The importance of birdsong recordings in the assessment and monitoring of rare species has been recognized previously (Gaunt and McCallum 2004). Our results show that song will be a useful tool for estimating the number of male and female Niceforo's Wrens and censusing the number of breeding pairs. The restricted dry forests of the Chicamocha Valley are the only habitat for this species. Recently, the dry forests of the Chicamocha river valley were declared an "important bird area" for sustaining globally threatened and restricted-range species (Freile and Santander 2005). Nonetheless, this area remains unprotected. The present study provides a basis for assessment and continued research on Niceforo's Wren and underscores the dire need for conservation in this threatened area.

\section{ACKNOWLEDGMENTS}

This research was conducted with the aid of a grant from the International Development Research Centre, Ottawa, and with support from the University of Windsor and Natural Sciences and Engineering Research Council of Canada to D.J.M. Recordings were obtained during research by S.V.V., J.E.P., and N.D. with funds from British Petroleum's Conservation Program and support from Fundación ProAves Colombia and The British Library. Ongoing support is provided by a Pamela and Alexander F. Skutch Research Award to S.V.V., and Fundación ProAves Colombia. We thank J. Avendaño, M. Beltran, N. Carreño, A. Delgadillo, M. J. La Rota, J. Torres, F. Valderrama, and K. Vargas for their help in the field. S.V.V. especially thanks D. Bradley for his valuable and ongoing support during the writing of this manuscript. We are very grateful to the reviewers for their valuable comments on the manuscript. 


\section{Literature Cited}

BirdLife International. 2000. Threatened Birds of the World. Lynx Edicions, Barcelona, Spain, and BirdLife International, Cambridge, United Kingdom.

BirdLife International. 2004. Thryothorus nicefori. In 2006 IUCN Red List of Threatened Species. [Online.] Available at www. iucnredlist.org.

Brewer, D. 2001. Wrens, Dippers and Thrashers. Yale University Press, New Haven, Connecticut.

Collar, N. J., And P. Andrew. 1988. Birds to Watch: The ICBP World Checklist of Threatened Birds. ICBP Technical Publication no. 8, International Council for Bird Preservation, Cambridge, United Kingdom.

Collar, N. J., M. J. Crosby, and A. J. Stattersfield. 1994. Birds to Watch 2: The World List of Threatened Birds. BirdLife Conservation Series no. 4, BirdLife International, Cambridge, United Kingdom.

Collar, N. J., L. P. Gonzaga, N. Krabbe, A. Madroño Nieto, L. G. Naranjo, T. A. Parker, and D. C. Wege. 1992. Threatened Birds of the Americas: The ICBP/IUCN Red Data Book, 3rd ed. International Council for Bird Preservation, Cambridge, United Kingdom.

Etter, A. 1993. Diversidad ecositémica en Colombia hoy. In Nuestra Diversidad Biológica (S. Cárdenas and H. D. Correa, Eds.). Fundación Alejandro Escobar, Colección María Restrepo de Ángel, CEREC, Bogotá, Colombia.

Freile, J. F., And T. Santander. 2005. Áreas importantes para la Conservación de las Aves en Colombia. Pages 117-281 in Áreas Importantes para la Conservación de las Aves en los Andes Tropicales: Sitios Prioritarios para la Conservación de la Biodiversidad (BirdLife International and Conservation International, Eds.). Serie de Conservación de BirdLife no. 14. Quito, Ecuador.

Gaunt, S. L. L., AND D. A. McCallum. 2004. Birdsong and conservation. Pages 343-362 in Nature's Music: The Science of Birdsong (P. Marler and H. Slabbekoorn, Eds.). Elsevier Academic Press, London.
Hilty, S. L., AND W. L. Brown. 1986. A Guide to the Birds of Colombia. Princeton University Press, Princeton, New Jersey.

Illes, A. E., M. L. Hall, and S. L. VehrenCamp. 2006. Vocal performance influences male receiver response in the Banded Wren. Proceedings of the Royal Society of London, Series B 273:1907-1912.

JANZEN, D. H. 1988. Tropical dry forests: The most endangered major tropical ecosystem. Pages 130-137 in Biodiversity (E. O. Wilson, Ed.). National Academy Press, Washington, D.C.

López-Lanús, B., And C. D. CAdena. 2002. Thryothorus nicefori. Pages 375-378 in Libro Rojo de Aves de Colombia (L. M. Renjifo, A. M. Franco-Maya, J. D. Amaya-Espinel, G. H. Kattan, and B. López-Lanús, Eds.). Serie Libros Rojos de Especies Amenazadas de Colombia, Instituto de Investigación de Recursos Biológicos Alexandex von Humboldt and Ministerio del Medio Ambiente, Colombia.

Mann, N. I., F. K. Barker, J. A. Graves, K. A. Dingess-Mann, AND P. J. B. SLATER. 2006. Molecular data delineate four genera of "Thryothorus" wrens. Molecular Phylogenetics and Evolution 40:750-759.

Mennill, D. J., and S. L. Vehrencamp. 2005. Sex differences in singing and duetting behavior of Neotropical Rufous-and-white Wrens (Thryothorus rufalbus). Auk 122:175-186.

Meyer de Schauensee, R. 1946. A new species of wren from Colombia. Notulae Naturae, no. 182.

Murphy, P. G., AND A. E. Lugo. 1986. Ecology of tropical dry forest. Annual Review of Ecology and Systematics 17:67-88.

Pennington, R. T., D. E. Prado, and C. A. Pendry. 2000. Neotropical seasonally dry forests and Quaternary vegetation changes. Journal of Biogeography 27:261-273.

Ridgely, R., AND G. Tudor. 1989. The Birds of South America, vol. 1: The Oscine Passerines. University of Texas Press, Austin.

Valderrama S. V., J. E. Parra, and N. Dávila. 2007. First nest description for Niceforo's Wren (Thryothorus nicefori): A critically endangered Colombian endemic songbird. Ornitologia Neotropical 18:313-318.

Associate Editor: A. M. Dufty, Jr. 